\title{
Biopsy Guidance
}

National Cancer Institute

\section{Source}

National Cancer Institute. Biopsy Guidance. NCI Thesaurus. Code C160875.

Any of various methods to assist in directing a biopsy needle into the area of interest. 